\title{
The atmospheric sulfur cycle over the Amazon Basin: 2. Wet season
}

\section{Citation}

Andreae, M. O., H. Berresheim, H. Bingemer, D. J. Jacob, B. L. Lewis, S.-M. Li, and R. W. Talbot. 1990. "The Atmospheric Sulfur Cycle over the Amazon Basin: 2. Wet Season." Journal of Geophysical Research 95 (D10): 16813. doi:10.1029/jd095id10p16813.

\section{Published Version}

doi:10.1029/JD095iD10p16813

\section{Permanent link}

http://nrs.harvard.edu/urn-3:HUL.InstRepos:14121772

\section{Terms of Use}

This article was downloaded from Harvard University's DASH repository, and is made available under the terms and conditions applicable to Other Posted Material, as set forth at http:// nrs.harvard.edu/urn-3:HUL.InstRepos:dash.current.terms-of-use\#LAA

\section{Share Your Story}

The Harvard community has made this article openly available.

Please share how this access benefits you. Submit a story.

Accessibility 


\title{
The Atmospheric Sulfur Cycle Over the Amazon Basin 2. Wet Season
}

\author{
M. O. Andreae,,$^{1,2}$ H. Berresheim, ${ }^{1,5}$ H. Bingemer, ${ }^{2}$ D. J. Jacob, ${ }^{3}$ \\ B. L. LEWIS, ${ }^{1}$ S.-M. LI, ${ }^{1}$ AND R. W. TALBOT ${ }^{4,6}$
}

\begin{abstract}
We determined the fluxes and concentrations of atmospheric sulfur species at ground level and from aircraft over the Amazon Basin during the 1987 wet season, providing a comprehensive description of the sulfur cycle over a remote tropical region. The vertical profile of dimethylsulfide (DMS) during the wet season was found to be very similar to that measured during the dry season, suggesting little seasonal variation in DMS fluxes. The concentrations of hydrogen sulfide $\left(\mathrm{H}_{2} \mathrm{~S}\right)$ were almost an order of magnitude higher than those of DMS, which makes $\mathrm{H}_{2} \mathrm{~S}$ the most important biogenic source species in the atmospheric sulfur cycle over the Amazon Basin. Using the gradient-flux approach, we estimated the flux of DMS at the top of the tree canopy. The canopy was a source of DMS during the day, and a weak sink during the night. Measurements of sulfur gas emissions from soils, using the chamber method, showed very small fluxes, consistent with the hypothesis that the forest canopy is the major source of sulfur gases. The observed soil and canopy emission fluxes are similar to those measured in temperate regions. The concentrations of $\mathrm{SO}_{2}$ and sulfate aerosol in the wet season atmosphere were similar to dry season values. The sulfate concentration in rainwater, on the other hand, was lower by about a factor of 5 during the wet season. Due to the higher precipitation rate, however, the wet deposition flux of sulfate was not significantly different between the seasons. The measured fluxes and concentrations of DMS, $\mathrm{H}_{2} \mathrm{~S}$, and $\mathrm{SO}_{2}$ were consistent with a model describing transport and chemistry of these sulfur species in the boundary layer. The concentrations of aerosol and the sulfate deposition rate, on the other hand, could only be explained by import of significant amounts of marine and anthropogenic sulfate aerosol into the Amazon Basin.
\end{abstract}

\section{INTRODUCTION}

The terrestrial biogenic sources of reduced sulfur gases and the role of these emissions as precursors of sulfate in aerosols and precipitation are one of the major open questions in our understanding of the natural sulfur cycle in the atmosphere [Andreae, 1990]. Recent work by Lamb et al. [1987] and Goldan et al. [1987] has contributed much to an improved assessment of reduced sulfur emissions from soils and plants in temperate regions. However, there is still little information on sulfur fluxes from the tropical continents, where most of the world's biomass and primary production are concentrated.

During the Amazon Boundary Layer dry season experiment (ABLE 2A), conducted during July 1985 in the central Amazon Basin, we determined the concentrations and fluxes of several atmospheric sulfur species, in particular, dimethylsulfide (DMS), methyl mercaptan (MeSH), hydrogen sulfide $\left(\mathrm{H}_{2} \mathrm{~S}\right)$, sulfur dioxide $\left(\mathrm{SO}_{2}\right)$, and aerosol sulfate $\left(\mathrm{SO}_{4}{ }^{-}\right)$ and methanesulfonate (MSA) [Andreae and Andreae, 1988]. In contrast to expectations based on earlier work, e.g., the study on sulfur gas fluxes from soils in temperate and

\footnotetext{
${ }^{1}$ Department of Oceanography, Florida State University, Tallahassee.

${ }^{2}$ Now at Biogeochemistry Department, Max-Planck-Institute for Chemistry, Federal Republic of Germany.

${ }^{3}$ Department of Earth and Planetary Sciences and Division of Applied Sciences, Harvard University, Cambridge, Massachusetts.

${ }^{4}$ Atmospheric Sciences Division, NASA Langley Research Center, Hampton, Virginia.

${ }^{5}$ Now at School of Geophysical Sciences, Georgia Institute of Technology, Atlanta.

${ }^{6}$ Now at Institute for the Study of Earth, Oceans and Space, University of New Hampshire, Durham.

Copyright 1990 by the American Geophysical Union.

Paper number 90JD00716.

0148-0227/90/90JD-00716\$05.00
}

subtropical regions by Adams et al. [1981] and the work in Africa reviewed by Delmas and Servant [1988], we found that sulfur gas emissions from the soils in Amazonia were quite low. Emissions from the plant canopy greatly exceeded those from the soils, with DMS and $\mathrm{H}_{2} \mathrm{~S}$ being the dominant species emitted. The total sulfur flux from the soil/plant system under dry season conditions was estimated to be of the order of $3 \mathrm{nmol} \mathrm{m} \mathrm{m}^{-2} \mathrm{~min}^{-1}$. The deposition flux of sulfate was somewhat higher, about $8 \mathrm{nmol} \mathrm{m}^{-2} \mathrm{~min}^{-1}$. The difference between emission and deposition fluxes was attributed to import of sulfur into the basin by long-range transport from marine and pollution-related sources, including biomass burning. Local pollution from the Manaus area could also have contributed to the sulfur deposition observed during the 1985 dry season experiment [Andreae and Andreae, 1988].

In this paper, we present the results from the ABLE 2B wet season experiment (April-May 1987) and compare them with the observations made during the 1985 dry season, in order to elucidate seasonal patterns in emission, transport, and deposition of sulfur species in Amazonia. The field measurements of sulfur species concentrations and fluxes are compared to predictions made with a model incorporating vertical transport and chemical transformations. The behavior of sulfate and MSA in rain is discussed in detail in a companion paper on the precipitation chemistry in Amazonia [Andreae et al., this issue].

\section{Methods: SAMPling AND ANALYSIS}

On the NASA Electra research aircraft, air was sampled from a Teflon manifold (8 $\mathrm{mm}$ ID), which was continuously flushed with outside air at a flow rate of about $50 \mathrm{~L} \mathrm{~min}^{-1}$. The Teflon tubing was guided through the hull of the aircraft by an aluminum pipe with its inlet about $20 \mathrm{~cm}$ away from the surface, which placed the intake well outside of the 
turbulent boundary layer of the aircraft. The flow rates and sample volumes for all species investigated were measured with integrating mass flowmeters (Teledyne HastingsRaydist). At ground level, air was pulled directly into the DMS and $\mathrm{H}_{2} \mathrm{~S}$ preconcentration devices.

The techniques used for sampling and determination of atmospheric DMS have been described in detail previously [Andreae et al., 1985]. DMS was preconcentrated by adsorption to gold wool contained in quartz glass tubes. Duplicate samples were collected simultaneously; the flow rate through each sampling tube was regulated to about $2 \mathrm{~L}$ $\min ^{-1}$. The sampling time varied from $10 \mathrm{~min}$ in the mixed layer and at ground level to about 1 hour at the highest flight levels. Scrubber tubes filled with $5 \% \mathrm{Na}_{2} \mathrm{CO}_{3}$ on Anakrom C22 (40/50 mesh) were placed in the sample airstream before the gold adsorption tubes. Freshly filled tubes were used for each flight. Laboratory experiments and the results of a recent intercomparison experiment have shown that these scrubber tubes are equally effective in preventing negative artifacts in the determination of DMS as other ozoneremoval devices (M. O. Andreae, unpublished data, 1989).

All samples were analyzed within 6 hours after each flight. Previous studies had shown that the DMS on the gold surface is stable for at least $\mathbf{1 0}$ days if the samples are stored in the dark. The determination of DMS consisted of thermal desorption followed by cryogenic trapping, chromatographic separation, and flame photometric detection [Andreae et al., 1985].

$\mathrm{H}_{2} \mathrm{~S}$ was determined by the technique of Natusch et al., [1972], with the modifications and analytical device designed by Jaeschke et al. [1980]. From the Teflon sampling manifold, air was drawn at 7-11 $\mathrm{L} \mathrm{min}^{-1}$ through silver nitrate impregnated filters (Microsorban-98, DELBAG Corp.) held in Teflon filter holders. Sampling times were approximately 1 hour. The sulfide collected on the filters was recovered by rinsing with dilute $\mathrm{NaOH} / \mathrm{NaCN}$ solution and subsequently determined fluorometrically by fluorescence quenching of dilute fluorescein mercuric acetate at $500 \mathrm{~nm}$ excitation and $520 \mathrm{~nm}$ emission wavelengths. The analytical procedure was calibrated prior to each analysis period using freshly prepared standard solutions of sodium sulfide. All samples were analyzed within 8 hours after collection. The results were corrected for the interference caused by the hydrolysis of atmospheric COS on the impregnated filters [Cooper and Saltzman, 1987]. This correction was made by placing two impregnated filters in series. Since the conversion efficiency of $\operatorname{COS}$ is only $1-2 \%$, the amount of $\operatorname{COS}$ converted on the second filter is essentially identical to that on the first, and an accurate correction can be made by subtracting the value obtained on the second filter from the total sulfide concentration measured on the first filter. The average COS correction was $10 \mathrm{ppt}$, about $20 \%$ of the $\mathrm{H}_{2} \mathrm{~S}$ signal in the boundary layer.

$\mathrm{SO}_{2}$ samples were collected from the same manifold, using a filter pack with a $\mathrm{K}_{2} \mathrm{CO}_{3}$-impregnated filter preceded by a Teflon filter to remove aerosols. To trap $\mathrm{SO}_{2}$, we used a fast-flow cellulose filter (Schleicher and Schuell, FF 2) impregnated with $\mathrm{K}_{2} \mathrm{CO}_{3}$ /glycerol. The preparation, storage, and blank behavior of the impregnated filters have been described in detail by Daum and Leahy [1983]. The collection efficiency and capacity of the impregnated filters for $\mathrm{SO}_{2}$ were studied in laboratory and field experiments [Andreae et al., 1988; Berresheim et al., 1990]. Under the meteorological conditions prevailing during ABLE $2 B$ and using sampling periods of 30-120 min, the collection efficiency of the impregnated filters was $>\mathbf{9 0} \%$ in the boundary layer and $>\mathbf{8 0} \%$ in the free troposphere.

The aerosol sampling system and procedures are described in detail elsewhere [Talbot et al., 1988, this issue (a)]. The filter unit contained two sequential 90-mm-diameter filters on polyethylene supports. The aerosol was collected and separated into coarse $(>1.0 \mu \mathrm{m}$ diameter) and fine particles on these two filter stages, the first consisting of a Nuclepore filter (nominal pore size $8.0 \mu \mathrm{m}$; 50\% cutoff diameter at the face velocity used: about $1.0 \mu \mathrm{m}$ [John et al., 1983]), the second a Zefluor filter (Gelman, nominal pore size $2.0 \mu \mathrm{m})$.

All filter samples were placed in polyethylene vials and extracted immediately following the flights with $10 \mathrm{~mL}$ of deionized water. (The Zefluor filters were first wetted with 1 $\mathrm{mL}$ of methanol.) The impregnated filters were treated with $10 \mathrm{~mL}$ of $0.06 \% \mathrm{H}_{2} \mathrm{O}_{2}$, whereby all sulfur (IV) species adsorbed on the filter were dissolved and converted to sulfate.

Rainwater samples were collected on an event basis by setting out polyethylene collectors during active precipitation only. The samples were placed in polyethylene bottles which had been rinsed with deionized water. Small amounts (about $1 \mathrm{~mL}$ ) of chloroform were added to prevent microbial growth. Further details on the sampling sites and protocol can be found in the work by Andreae et al. [this issue].

Sulfate in both aerosol and impregnated filter extracts was determined by ion chromatography using the Dionex HPICAS4A column and $1.7 \mathrm{mM}\left(\mathrm{mmol} \mathrm{L}^{-1}\right) \mathrm{NaHCO}_{3} / 1.0 \mathrm{mM}$ $\mathrm{Na}_{2} \mathrm{CO}_{3}$ eluent. The carbonate matrix in the impregnated filter solutions had no significant effect on the retention time and height of the sulfate peaks.

The results are presented as molar mixing ratios (mole of substance per mole of air). We use the unit "ppt" to represent this mixing ratio (multiplied by $10^{12}$ ); for gases this unit is equivalent to "pptv."

\section{Results AND Discussion}

\section{Sampling Environment and Meteorological Conditions}

The ABLE 2B experiment took place in April/May 1987, during the late part of the wet season. The large-scale meteorological conditions prevailing during the experiment have been described by Harriss et al. [this issue] and $\mathbf{M}$. Garstang et al. (The Amazon Boundary Layer Experiment (ABLE 2B): A meteorological perspective, submitted to Bulletin of the American Meteorological Society, 1989). The circulation was dominated by flow from the east to southeast, with the Intertropical Convergence Zone (ITCZ) either passing over Manaus or lying slightly to the north. An anticylcone, present for most of the time over central Brazil, with its center near Brasilia, caused inflow of air from the dry tropical regions of central Brazil into the Amazon Basin. Occasional shifts in the position of the ITCZ and the strength of the northern hemisphere subtropical anticyclone resulted in the injection of pulses of air from the northern hemisphere, which may have introduced dust from the Saharan region [Talbot et al., this issue (a)]. This dust is characteristically associated with aerosol sulfate and nitrate originating from pollution and/or biomass burning [Savoie et al., 1989]. 
TABLE 1. Summary of Sulfur Species Concentrations (in ppt) in the Atmosphere Over the Amazon Basin in the Dry and Wet Seasons

\begin{tabular}{|c|c|c|c|c|c|c|}
\hline \multirow[b]{2}{*}{ Species } & \multicolumn{2}{|c|}{ Ground Level } & \multicolumn{2}{|c|}{ Boundary Layer } & \multicolumn{2}{|c|}{ Free Troposphere } \\
\hline & Dry & Wet & Dry & Wet & Dry & Wet \\
\hline $\mathrm{H}_{2} \mathrm{~S}$ & $\begin{array}{c}30 \pm 12 \\
(21)\end{array}$ & 一 & - & $47 \underset{(6)}{ \pm} 21$ & 一 & $7 \pm 7$ \\
\hline MeSH & $\begin{array}{c}5.7 \pm 6.4 \\
(35)\end{array}$ & - & $\begin{array}{c}0.9 \pm 1.3 \\
(50)\end{array}$ & - & $<0.5$ & - \\
\hline DMS & $\begin{array}{c}16 \pm 10 \\
(35)\end{array}$ & $\begin{array}{c}16 \pm 10 \\
(99)\end{array}$ & $\begin{array}{c}9.1 \pm 6.7 \\
(60)\end{array}$ & $\begin{array}{c}7.2 \pm 3.1 \\
(63)\end{array}$ & $\begin{array}{c}1.1 \pm 0.8 \\
(23)\end{array}$ & $\begin{array}{c}0.9 \pm 0.5 \\
(31)\end{array}$ \\
\hline $\mathrm{SO}_{2}$ & - & - & $\begin{array}{c}27 \pm 10 \\
(24)\end{array}$ & $\begin{array}{c}24 \pm 14 \\
(13)\end{array}$ & $\begin{array}{c}18 \pm 16 \\
(15)\end{array}$ & $\begin{array}{c}15 \pm 8 \\
\text { (12) }\end{array}$ \\
\hline $\begin{array}{l}\text { Sulfate } \\
\text { (aerosol) }\end{array}$ & $\begin{array}{c}118 \pm 119^{*} \\
(11)\end{array}$ & $\begin{array}{c}67 \pm ? \dagger \\
(31)\end{array}$ & $\begin{array}{c}129 \pm 50 \\
(30)\end{array}$ & $\begin{array}{c}76 \pm 56 \\
(14)\end{array}$ & $\begin{array}{c}16 \pm 7 \\
(19)\end{array}$ & $\begin{array}{c}11 \pm 4 \\
(13)\end{array}$ \\
\hline MSA & - & - & $5.9 \pm 1.8$ & $<2.2 \pm 1.2 \ddagger$ & $1.4 \pm 0.7$ & - \\
\hline
\end{tabular}

Values in parentheses are number of samples.

*From Artaxo et al. [1988].

$\dagger$ From Artaxo et al. [this issue]. No standard deviation given in original source.

‡Upper limit. Values were below detection limit (about $0.6 \mathrm{ppt}$ ) on nine of 16 flights.

Samples were collected at the ground to investigate sulfur species emission and deposition fluxes, and from aircraft to measure the horizontal and vertical distribution of these species in the lower troposphere. Ground-based sampling was conducted from a 45-m micrometeorological tower at the Ducke Forest Reserve research site $(25 \mathrm{~km}$ from Manaus). This facility is located within a large, relatively undisturbed rain forest area occupied by terra firme forest with an average canopy height of about $30 \mathrm{~m}$ and emergents to $35 \mathrm{~m}$. The micrometeorology at the site is discussed by Fitzjarrald et al. [this issue]. Most of the research flights were conducted over large, almost completely undisturbed regions of Amazonian rain forest. Only near rivers and in the periphery of the few large inhabited areas (e.g., Manaus, Santarem, and Belém) were agricultural and industrial activity present. In order to obtain information on large-scale trends in the distribution of atmospheric constituents, we conducted survey flights which covered the region from Manaus (near $60^{\circ} \mathrm{W}$ ) to the Atlantic coast (near $48^{\circ} \mathrm{W}$ ) [Harriss et al., this issue].

\section{Reduced Sulfur Species: Aircraft Measurements}

In Table 1 we present a summary of the sulfur species concentrations over the Amazon Basin during the wet and dry seasons. In the case of DMS, we were able to obtain a comprehensive data set for both seasons; technical problems made MeSH measurements during the wet season impossible, and for $\mathrm{H}_{2} \mathrm{~S}$ we have ground-level data only for the dry season and aircraft data only for the wet season.

The concentrations of DMS in the wet and dry seasons were identical within the variability of the data. This is evident in Figure 1, where the data from both seasons are plotted versus altitude. During most flights, the concentration of DMS was almost constant from the lowest sampling level (about $150 \mathrm{~m}$ ) to the top of the mixed layer (about 300 to $1500 \mathrm{~m}$, depending on meteorological conditions and time of day). It decreased through the cloud convection layer (CCL) to values near 1 ppt in the free troposphere. DMS showed no statistically significant diel variation in the mixed layer, although there was a tendency for high concentrations to occur between 1000 and 1200 local time (LT), which was probably due to fast transport of DMS upward from the forest into the growing mixed layer.

The cross-basin survey between Manaus and Belém during the wet season (April 23-24, 1989) confirmed the results of the dry season experiment (Figure 2). Over the Amazonas Estuary near Belém, DMS levels exceeded 70 ppt (only a lower limit can be given, as the instrument went off-scale at $70 \mathrm{ppt}$ ); they decreased rapidly between the coast (near $48^{\circ} \mathrm{W}$ ) and $52^{\circ} \mathrm{W}$. West of this longitude, values typical of the interior Amazon Basin were measured. The steep longitudinal gradient observed here cannot be used as evidence for a short atmospheric lifetime of DMS, however. Streamline charts show that airmass transport was nearly parallel to the coast (Figure 3), so that marine air was sampled only very close to the coast. Consequently, the rapid transition from predominantly marine to predominantly continental air masses along the flight track, rather than fast photochemical oxidation of DMS, appears to be responsible for the observed sharp geographical gradient in DMS concentration.

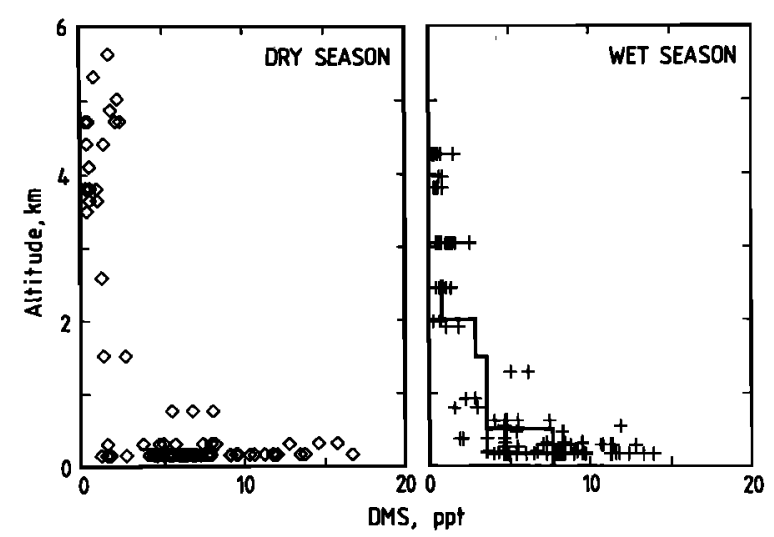

Fig. 1. Vertical distribution of dimethylsulfide (DMS) in the atmosphere over the central Amazon Basin during the dry and wet seasons. For the wet season, the results of the model simulation are superimposed (see text). 


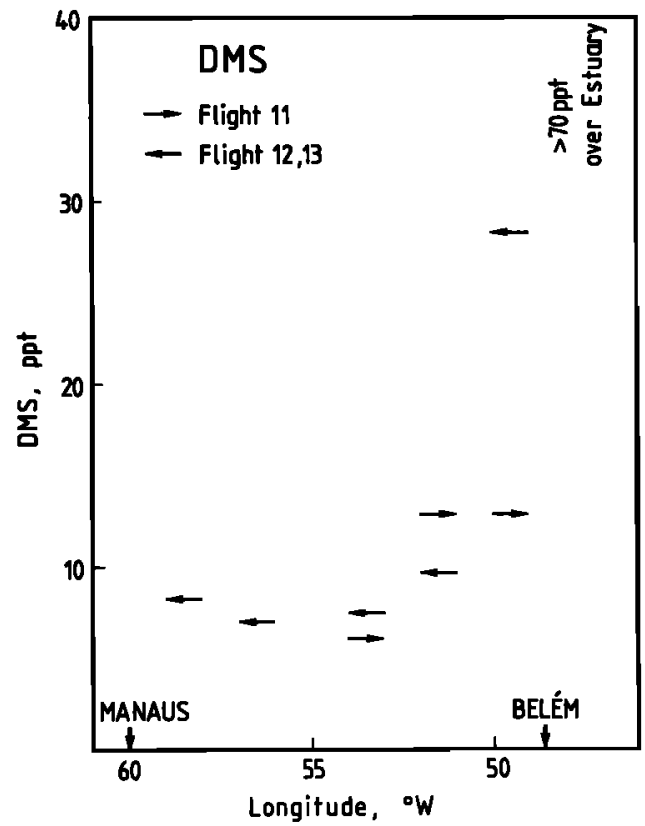

Fig. 2. Geographical trend in the concentration of dimethylsulfide (DMS) in the atmospheric mixed layer along a transect from Manaus to Belém, Brazil (flight 11, April 23, 1989; flight 12 and 13, April 24, 1987).

\section{Sources and Fluxes of Reduced Sulfur Species}

In order to investigate the source mechanisms and fluxes of reduced sulfur species into the atmosphere from the Amazon forest ecosystem, we conducted measurements using soil chambers and a micrometeorological mast at the Ducke Forest Reserve. Both soils and plants have been shown to emit sulfur gases (for a recent review, see Andreae [1990]). We measured the emissions of DMS and $\mathrm{H}_{2} \mathrm{~S}$ from the yellow clay soil dominant in the region at two sites in the forest near the micrometeorological tower. The measurement sites are described in more detail by Bakwin et al. [this issue (a)]. The chamber was Teflon lined and had a diameter of $25 \mathrm{~cm}$. A ring was inserted in the soil and left there for several weeks before the first samples were taken. Leaf litter present on the soil was not removed. The soil temperature was near $27^{\circ} \mathrm{C}$ and showed little variation through the diel cycle or between sampling days. For the measurements, a lid was placed on the ring and the chamber flushed continuously with ambient air at a flow rate of $1 \mathrm{~L} \mathrm{~min}^{-1}$. This stream was sampled and the soil emission flux calculated from the difference between the concentration measured in the chamber effluent and in ambient air. The DMS flux at the first site was $0.048 \pm 0.021 \mathrm{nmol} \mathrm{m} \mathrm{min}^{-1}(n=6)$, at the other $0.031 \pm 0.027 \mathrm{nmol} \mathrm{m}^{-2} \mathrm{~min}^{-1}(n=8)$. The mean of these fluxes, $0.040 \mathrm{nmol} \mathrm{m}^{-2} \mathrm{~min}^{-1}$, is a factor of 10 lower than the DMS flux measured during the dry season from a similar soil nearby. The emission of $\mathrm{H}_{2} \mathrm{~S}$, which averaged $0.07 \mathrm{nmol}$ $\mathrm{m}^{-2} \mathrm{~min}^{-1}$ during the dry season, was below the limit of detection (about $0.03 \mathrm{nmol} \mathrm{m} \mathrm{min}^{-1}$ ) during the wet season. The soil emissions of sulfur gases observed during the wet season in Amazonia are at the low end of the range reported by Lamb et al. [1987] for soils in the United States, and lower than most of the values published for other regions [e.g., Adams et al., 1981; Staubes et al., 1989], whereas the fluxes measured in the dry season were in closer agreement with literature values. This difference is probably due to the high water content of the soils during the wet season and the resulting low soil porosity. Similarly, Bakwin et al. [this issue $(a)$ ] found that the NO fluxes from soils at Ducke Reserve were lower by a factor of 5 during the wet season. The radon fluxes from the soils were also low during the wet season, consistent with waterlogging of the soils and the resulting low porosity [Trumbore, 1988].

The emission of sulfur gases from plants is well established in the literature [Andreae, 1990, and references therein; Rennenberg, 1987]. In a recent study on sulfur gas emissions from vegetated soils and crops, emission fluxes of 0.2-2 $\mathrm{nmol} \mathrm{m} \mathrm{min}^{-1}$ were observed [Lamb et al., 1987; Goldan et al., 1987]. The mean sulfur flux from deciduous trees was $0.9 \mathrm{nmol} \mathrm{m}^{-2} \mathrm{~min}^{-1}$ during summer conditions in the eastern United States. $\mathrm{H}_{2} \mathrm{~S}$ and DMS were found to be emitted in comparable amounts. During the ABLE 2A dry season experiment, we estimated the sulfur emission flux from the Amazon forest using a gradient-flux technique [Andreae et al., 1988]: the fluxes were 0.8, 0.4, and $\leq 1.6$ nmol m $\mathrm{m}^{-2} \min ^{-1}$ for DMS, MeSH, and $\mathrm{H}_{2} \mathrm{~S}$, respectively. Since these fluxes were considerably larger than the soil emissions, we proposed that the plant canopy made a major contribution to the sulfur emissions from the overall ecosystem.

During the ABLE 2B wet season experiment, we determined the concentration of DMS at six elevations in the forest: $0,12,19,27,35$, and $41 \mathrm{~m}$. A total of 23 profiles were obtained in the time period of April 12-30, 1987. The vertical profiles of DMS in the forest are shown in Figure 4 as a function of the time of day. The data shown are means and

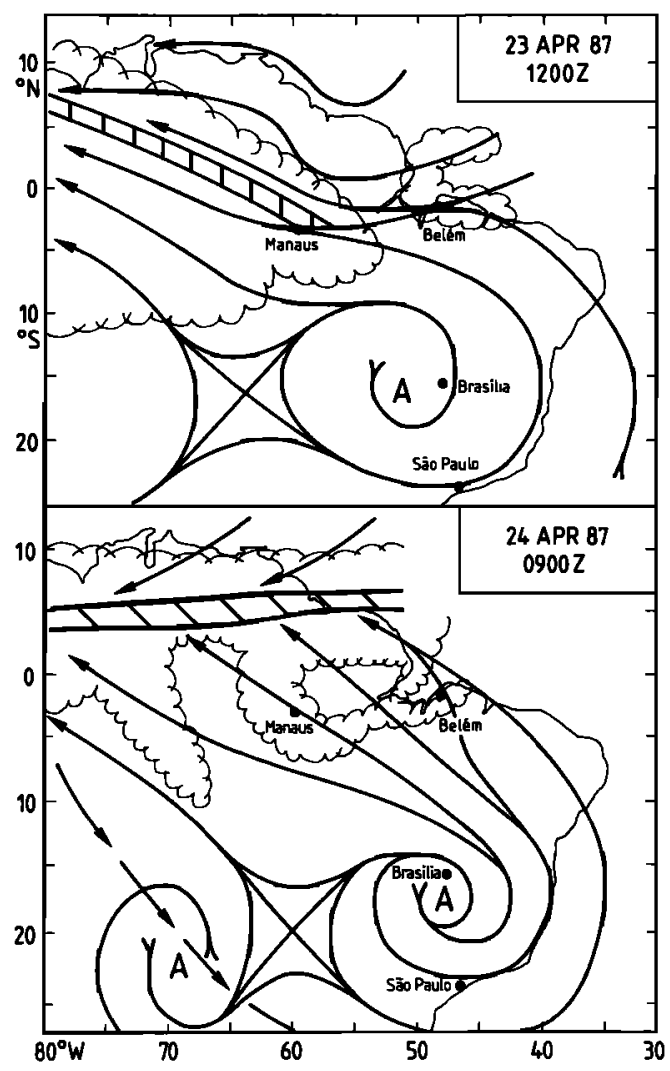

Fig. 3. Streamline charts for the $700-\mathrm{hPa}$ level and weather synopsis over western South America for April 23 and 24, 1987. 


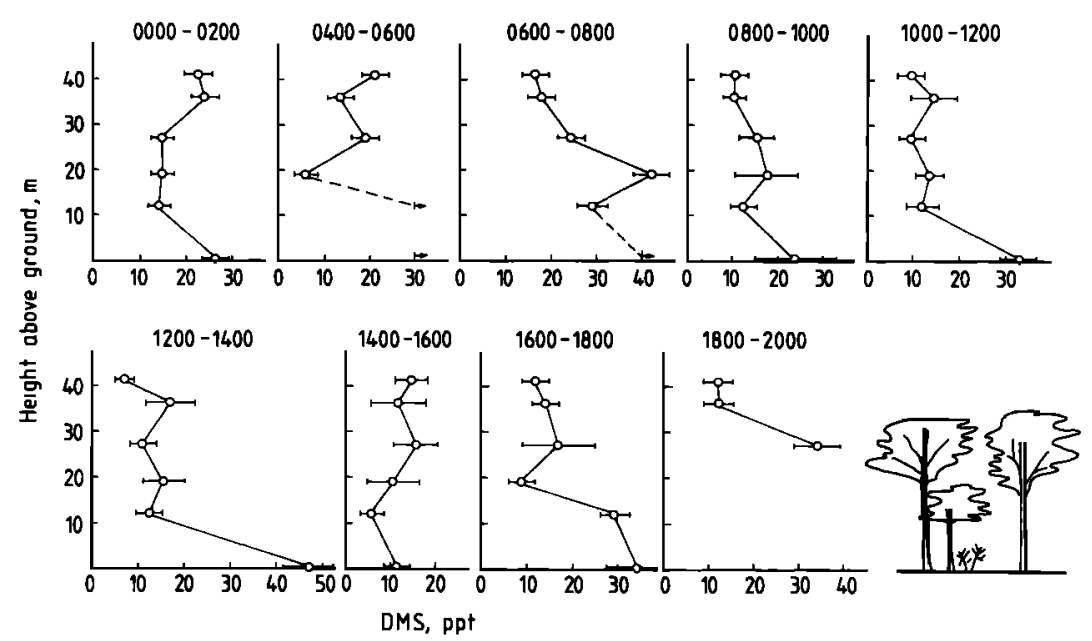

Fig. 4. Diel variation of the vertical profile of DMS in the Amazon rainforest during the wet season. A schematic representation of the canopy structure is indicated at bottom right. Data represent mean values for the time intervals indicated above the profiles (local time). (See text for explanation of error bars.)

standard errors, with the exception of the times before 0800 and after 1800 , when only single profiles were available and where the error bars represent the analytical uncertainty. Since data from different days are combined in this figure and significant day-to-day variations in the concentrations of DMS in the forest were observed, this figure is intended to show the changes in the shape of the vertical gradients, rather than changes in absolute concentration as a function of time of day.

The diel cycle of the vertical distribution of DMS, as shown in Figure 4, reflects the sources and sinks of this species as well as the forest micrometeorology. The continuous emission of DMS from the soils is reflected in a maximum at the soil surface level, which is present at all hours. (In the 1400-1600 period, the soil-level maximum appears to be absent; however, this data point represents only one measurement on a day with generally low DMS levels.) At midnight, the concentration gradients are fairly weak, consistent with the thermal instability observed in the forest at this time. At night, DMS concentrations decrease from the highest sampling level $(41 \mathrm{~m})$ downward into the forest canopy. (The canopy top is at $35 \mathrm{~m}$, its maximum density at $27 \mathrm{~m}$.) This gradient suggests a downward flux from the overlying atmosphere and uptake by the canopy. Concentrations increase again from the lower canopy to the soil surface, indicating that emission from the soil surface continues at night and that the canopy acts as a sink for both DMS emitted from the soil and DMS mixed down from the atmosphere above the forest. The gradient at the top of the canopy reverses after sunrise, indicating the onset of upward flux from the canopy. Around midday, as insolation of the leaves reaches its highest values, a strong DMS maximum develops in the canopy. The DMS maximum at soil level is also most pronounced around midday due to the higher degree of convective stability inside the forest at this time [Molion et al., 1988]. This stability results from the air being heated at the canopy level, while remaining relatively cool near the ground.

Simultaneous with the determination of the DMS profiles, the concentrations and fluxes of $\mathrm{CO}_{2}$ and $\mathrm{O}_{3}$ were measured by Fan et al. [this issue] using the eddy correlation tech- nique. The $\mathrm{O}_{3}$ and $\mathrm{CO}_{2}$ gradients between $27 \mathrm{~m}$ (within the canopy) and $41 \mathrm{~m}$ (above the tree tops) and the fluxes were used to determine exchange velocities which show a characteristic diel variation with small values at night and a midday maximum. DMS gradient data were grouped into 2-hour time intervals, and the mean gradients for each time interval multiplied with the corresponding exchange velocity (S.-M. Fan, personal communication, 1989) to obtain an estimate for the DMS flux between the canopy and the overlying atmosphere (Table 2). As is the case for $\mathrm{CO}_{2}$ and $\mathrm{O}_{3}$, a clear diel variation is present in the flux of DMS (Figure 5), with a pronounced midday maximum and low values at night. The downward gradient in DMS concentration observed between midnight and $0600 \mathrm{LT}$ results in a downward flux of DMS during the night; however, due to the low exchange velocity at this time, the magnitude of this deposition flux is rather small.

Integration of the exchange flux between forest and atmosphere throughout the 24-hour cycle results in an upward

TABLE 2. DMS Flux From the Rain Forest Canopy to the Overlying Atmosphere

\begin{tabular}{cccc}
\hline $\begin{array}{c}\text { Time of day } \\
\text { Interval, } \\
\text { hours }\end{array}$ & $\begin{array}{c}\text { Exchange } \\
\text { Velocity, } \\
\text { cm s }\end{array}$ & $\begin{array}{c}\text { DMS } \\
\text { Gradient, } \\
\text { ppt }\end{array}$ & $\begin{array}{c}\text { DMS } \\
\text { Flux, } \dagger \\
\text { nmol m }^{-1} \text { min }^{-1}\end{array}$ \\
\hline $0000-0200$ & 0.50 & -7.3 & -0.09 \\
$0200-0400$ & 0.50 & - & - \\
$0400-0600$ & 0.50 & -2.0 & -0.02 \\
$0600-0800$ & 1.42 & 7.8 & 0.28 \\
$0800-1000$ & 5.0 & $4.9 \pm 3.4$ & $0.62 \pm 0.42$ \\
$1000-1200$ & 17.0 & $1.7 \pm 3.6$ & $0.72 \pm 1.5$ \\
$1200-1400$ & 17.0 & $4.0 \pm 1.4$ & $1.7 \pm 0.6$ \\
$1400-1600$ & 17.0 & $0.7 \pm 2.3$ & $0.21 \pm 0.98$ \\
$1600-1800$ & 10.0 & $5.0 \pm 3.5$ & $1.2 \pm 0.9$ \\
$1800-2000$ & 1.0 & 22.4 & 0.56 \\
$2000-2200$ & 1.0 & - & - \\
$2200-2400$ & 1.0 & - & - \\
\hline
\end{tabular}

Means and standard errors are given where several measurements in given time interval were made.

*Between 27- and 41-m height.

†Positive in the upward direction. 


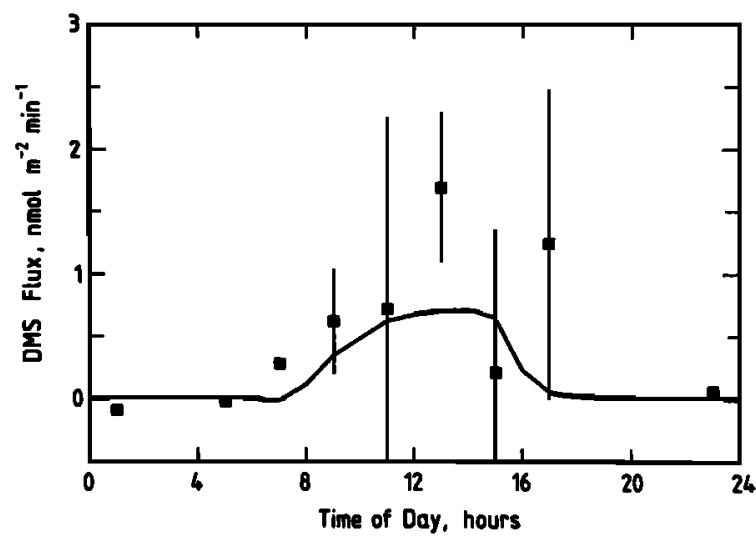

Fig. 5. Flux of DMS between the Amazon forest canopy and the overlying atmosphere during the wet season. The squares indicate the flux estimates obtained from the observed gradients and exchange coefficients. Error bars show one standard deviation for time intervals where multiple measurements were available. The solid and dashed lines represent the source characteristics used in the model (see text).

flux of $0.46 \pm 0.20 \mathrm{nmol} \mathrm{m} \mathrm{min}^{-1}$ ( \pm 1 standard error). This value is somewhat lower than the DMS flux measured during the dry season $\left(0.8 \mathrm{nmol} \mathrm{m} \mathrm{min}^{-1}\right)$, but in view of the uncertainties involved in estimating fluxes using the gradient-flux technique, this difference is of marginal significance. As already observed during the dry season experiment, the flux of DMS at the canopy top far exceeds the soil emission flux, making the canopy the dominant source of this species.

In studies on the emission of sulfur gases from deciduous trees, Lamb et al. [1987] found that $\mathrm{H}_{2} \mathrm{~S}$ and DMS were emitted at about the same rate and that daytime emission rates ranged from about 0.06 to $2.5 \mathrm{nmol} \mathrm{kg} \mathrm{min}^{-1}$ (relative to dry biomass) with a mean of about $0.3 \mathrm{nmol} \mathrm{\textrm {kg } ^ { - 1 }}$ $\mathrm{min}^{-1}$. Since their vegetation enclosures contained mostly leaves and small branches, and a tropical rain forest has a standing stock of about $1-4 \mathrm{~kg} \mathrm{~m}^{-2}$ of this type of biomass [Walter and Breckle, 1984], a DMS flux of about 0.3-1.2 $\mathrm{nmol} \mathrm{m} \mathrm{min}^{-1}$ would be predicted on the basis of Lamb et al.'s data. In view of the wide range of emission fluxes recorded by these authors and the uncertainty of our emission estimate, the agreement between the two estimates can be considered satisfactory.

\section{$\mathrm{SO}_{2}$, Aerosol Sulfate, and Methanesulfonate}

$\mathrm{SO}_{2}$ (Figure 6) and aerosol MSA and sulfate (Figure 7) were determined in samples collected from the Electra aircraft. The aerosol chemistry during ABLE 2B is described in detail in a companion paper [Talbot et al., this issue (a)], and only sulfate and methanesulfonate will be discussed here. A ground-level aerosol sampling program was conducted during ABLE $2 A$ and ABLE $2 B$ by another group [Artaxo et al., 1988, this issue].

The concentrations of $\mathrm{SO}_{2}$ during the wet season were very similar to the dry season levels (Table 1), especially when only those dry season $\mathrm{SO}_{2}$ data are considered which were collected before the onset of the impact of biomass burning. $\mathrm{SO}_{2}$ levels decrease slightly with altitude, again at about the same rate as during the dry season. Our $\mathrm{SO}_{2}$ concentrations from both seasons are much lower than

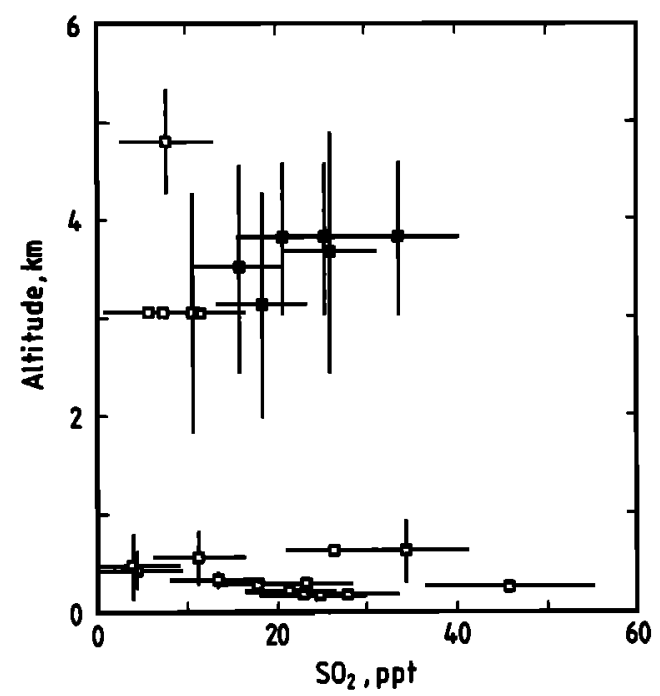

Fig. 6. Vertical distribution of sulfur dioxide $\left(\mathrm{SO}_{2}\right)$ in the atmosphere over the central Amazon Basin during the wet season. Horizontal error bars represent measurement uncertainty, vertical bars indicate the altitude range over which the samples were collected.

previously published data from the wet tropics; Lodge et al. [1974] give a mean concentration at Ducke Reserve of 0.3 $\mathrm{ppb}$, an order of magnitude above our value. Delmas and Servant [1983] obtained a mean $\mathrm{SO}_{2}$ concentration of 0.24 $\mathrm{ppb}$ in the Ivory Coast. The reason for this discrepancy is not clear; the high $\mathrm{SO}_{2}$ levels found in earlier studies may be related to the presence of anthropogenic emissions near the ground-sampling sites (vehicles, generators, etc.), or to regional air pollution. CO measurements by Kirchhoff and Marinho [this issue] have shown, for example, that Ducke Reserve is periodically under the influence of the urban plume from Manaus.

The mean sulfate aerosol concentration given in Table 1 was calculated by first averaging the data for each flight day, and then calculating the mean of these daily averages. This

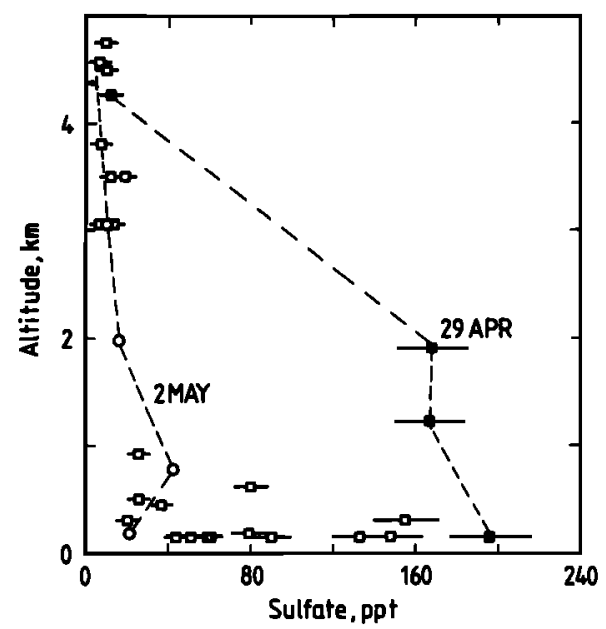

Fig. 7. Vertical distribution of aerosol sulfate $\left(\mathrm{SO}_{4}{ }^{-}\right)$in the atmosphere over the central Amazon Basin during the wet season. Solid squares represent data from the dust episode of April 29, 1989, circles from "clean" period on May 2, 1989, open squares from remaining flights. Error bars indicate measurement uncertainty. 


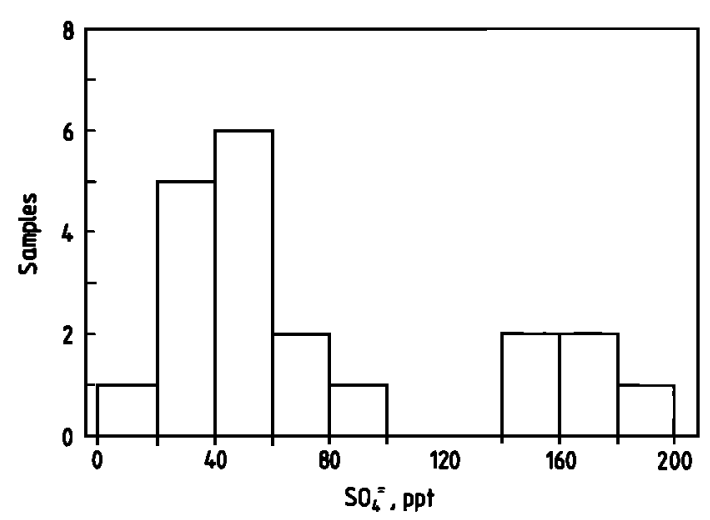

Fig. 8. Frequency distribution of aerosol sulfate concentrations in the atmosphere boundary layer during the wet season.

was done to remove potential bias due to different numbers of samples collected on individual flight days. The same averaging procedure was applied to aerosol methanesulfonate. In this case, however, most of the concentrations were below the limit of detection, so that the MSA value in Table 1 is an upper limit. MSA was not correlated significantly with sulfate in the aerosol samples from the central Amazon Basin, probably as a result of the diversity of source components for these two species. In the two aerosol samples collected over the coastal area, non-seasalt sulfate and MSA were both elevated (nss $-\mathrm{SO}_{4}^{=}, 42$ and $116 \mathrm{ppt}$; MSA, 4.4 and $12 \mathrm{ppt})$. The MSA/nss $-\mathrm{SO}_{4}^{=}$ratio $(0.044$ and 0.081 ) in these samples is similar to values found throughout the remote marine tropics [Saltzman et al., 1986]. When these two samples are excluded from the data set, there is no significant correlation between sodium and MSA. This may either be due to the existence of nonmarine sources of MSA, e.g., the oxidation of terrestrial biogenic DMS, or to differential removal of sodium and MSA due to differences in their aerosol size distribution.

No major differences are evident between the sulfate concentrations we measured using airborne sampling and ion-chromatographic analysis and those obtained by Artaxo et al. [1988, this issue] using ground-level sampling and analysis by photon-induced $\mathrm{X}$ ray emission (PIXE). This suggests that airborne sampling did not introduce any substantial bias. The sulfate value given in Table 1 for the wet season boundary layer represents a mean concentration of aerosol sulfate throughout the study. This mean value is, however, the result of compounding data from two rather distinct distributions, as the composite vertical plot in Figure 7 and the frequency distribution of sulfate concentrations (Figure 8) show. The bimodal character of the frequency histogram reflects the existence of two different types of air masses over central Amazonia, one showing strong influence of advective input of sulfate (and nitrate) aerosol by longrange transport, the other approximating "background" conditions. In the vertical distributions (Figure 7), this is exemplified by the data from May 2 (flight 18), representing a day with background conditions (and possibly influenced by a large rainfall event the previous day), and from April 29 (flight 16), which took place during a long-range transport event. The high sulfate levels during long-range transport episodes are always accompanied by elevated levels of aerosol nitrate, and usually coincide with high loadings of

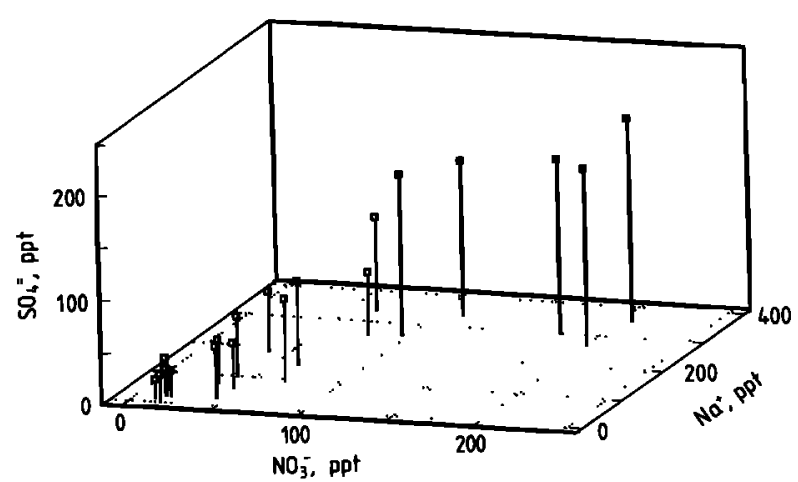

Fig. $9 a$

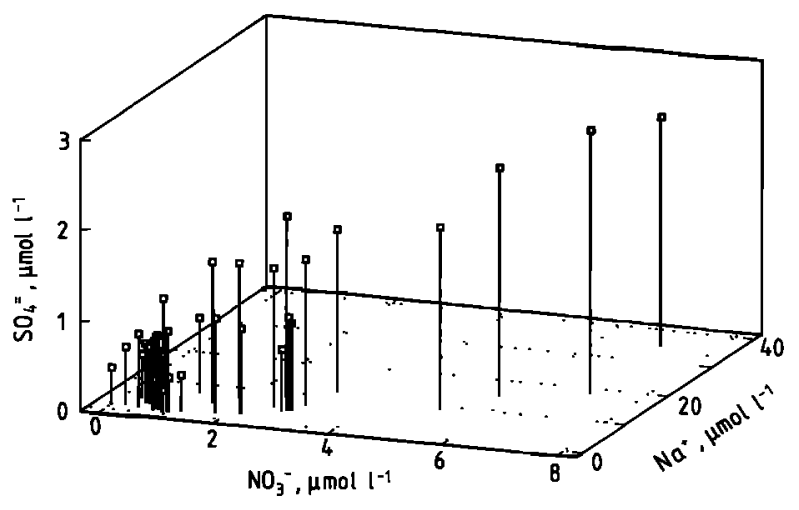

Fig. $9 b$

Fig. 9. Three-dimensional plot of sulfate versus nitrate and sodium in $(a)$ boundary layer aerosols and $(b)$ precipitation from central Amazonia. The solid squares in Figure $9 a$ denote samples taken during dust episodes.

mineral dust in the atmosphere. In several instances they appear to be related to transport events of Saharan dust across the Atlantic Ocean [Talbot et al., this issue (a)]. The ultimate source of sulfate and nitrate in this aerosol remains unclear; fossil fuel combustion in the Mediterranean region and biomass burning in Africa may both contribute [Savoie et al., 1989]. In addition, anthropogenic emissions from the densely populated regions in coastal Brazil are also likely to be transported to the study region, as suggested by the streamline charts (Figure 3).

The different sources of aerosol sulfate in the central Amazon Basin are evident in Figure 9, where sulfate is plotted against sodium and nitrate. In Figure $9 a$, which shows the aerosol data, the samples collected during longrange transport episodes are represented by solid symbols. The cluster of three points with the highest nitrate values is from the dust event of April 29 [cf. Talbot et al., this issue (a)]. It is obvious from this graph that high concentrations of sulfate always coincide with high levels of nitrate and sodium. An analysis of the sodium/chloride ratio in aerosol and rain shows that, even over central Amazonia, aerosol sodium is predominantly of marine origin [Andreae et al., this issue]. The observed association between sodium and sulfate thus suggests that part of the aerosol sulfate is also of marine origin. The relationship between sulfate and nitrate, on the other hand, points to a combustion-related source component from fossil fuel or biomass combustion, or a mixture of both. The simultaneous enrichment in the marine and the combustion-related components is due to the fact that enhanced advection of combustion-derived aerosols 
from either coastal Brazil or from Africa is necessarily always accompanied by increased inputs of marine aerosol.

The combined influence of the combustion and marine source components can be represented quantitatively by the multivariate regression of sulfate on sodium and nitrate. For this calculation, only the samples from the central Amazon Basin were used in order to prevent any bias from the coastal data. The resulting regression equation is

$$
\begin{aligned}
{\left[\mathrm{SO}_{4}{ }^{=}\right]=(12.2 \pm 5.7)+(0.130} & \pm 0.050)\left[\mathrm{Na}^{+}\right] \\
& +(0.67 \pm 0.10)\left[\mathrm{NO}_{3}^{-}\right]
\end{aligned}
$$

(Coefficients and standard errors are given in parentheses.)

The regression explains $92 \%$ of the variance, with sodium contributing $75 \%$ and nitrate $17 \%$. Inserting the mean concentrations of sodium (149 ppt) and nitrate (69 ppt) into this equation reveals that of the $76 \mathrm{ppt}$ sulfate present in the aerosol over central Amazonia, 25\% is marine (19 ppt) and about $60 \%$ combustion-related ( $46 \mathrm{ppt}$ ), with only about $15 \%$ (12 ppt) of local, biogenic origin.

Similar conclusions are reached based on the sulfate, sodium, and nitrate content of rain in the Amazon Basin during ABLE 2B, shown in Figure $9 b$ [cf. Andreae et al., this issue]. The volume-weighted mean sulfate concentration in precipitation during the wet season was $0.9 \mu \mathrm{mol} \mathrm{L}{ }^{-1}$. This value is among the lowest reported in the literature for any region on Earth, including the polar regions. Multivariate regression of sulfate on sodium and nitrate indicates that about one third of this amount $\left(0.32 \mu \mathrm{mol} \mathrm{L}{ }^{-1}\right)$ is of local, biogenic origin, with the remainder supplied in about equal parts from marine and combustion sources. The difference between the relative contributions of local biogenic sources to sulfate in aerosol (about 16\%) and rain (about 35\%) may, in part, be explained by the sulfate in cloud and rainwater being derived from both the scavenging of aerosol and the dissolution and oxidation of $\mathrm{SO}_{2}$. Since much of the $\mathrm{SO}_{2}$ over central Amazonia appears to be of biogenic origin (see below), a higher biogenic contribution is to be expected in precipitation than in aerosol. The biogenic component of the sulfate deposition $\left(3.8 \mu \mathrm{mol} \mathrm{m} \mathrm{m}^{-2} \mathrm{~d}^{-1}\right.$ of a total sulfate deposition of $10.6 \mu \mathrm{mol} \mathrm{m} \mathrm{m}^{-2} \mathrm{~d}^{-1}$ ) corresponds to a deposition flux of $2.6 \mathrm{nmol} \mathrm{m}^{-2} \mathrm{~min}^{-1}$, somewhat greater than our model-based estimate of the biogenic emission flux $1.4 \mathrm{nmol}$ $\mathrm{m}^{-2} \mathrm{~min}^{-1}$ (see below). This agreement must be considered satisfactory in view of the uncertainties involved in both estimates.

The sulfate concentrations in the free troposphere over Amazonia, $11 \pm 4 \mathrm{ppt}$ in the wet season and $16 \pm 7 \mathrm{ppt}$ in the dry, are among the lowest reported in the literature. Our sulfate measurements over the remote temperate oceans give values around $180 \mathrm{ppt}$ in the northern and around $35 \mathrm{ppt}$ in the southern hemisphere [Andreae et al., 1988; Berresheim et al., 1990]. Only during one of the flights over the southern hemisphere ocean did we observe a sulfate level (14 ppt) similar to those found over Amazonia. Sulfate measurements made on Mauna Loa, in the free troposphere in the tropics, show much higher levels throughout most of the year (in the hundreds of ppt), attributed by the authors to long-range transport and volcanic influence [Galasyn et al., 1987]. Only during the winter were values around $10 \mathrm{ppt}$ regularly measured there. These results show that in the absence of volcanic or anthropogenic input, natural sulfate levels in the remote free troposphere are extremely low.

\section{Model of Biogenic Sulfur Cycle}

Above we obtain an estimate of the DMS emission flux from the Amazon forest by using the observed DMS concentration gradients at the canopy top, in combination with average vertical exchange coefficients derived from $\mathrm{O}_{3}$ and $\mathrm{CO}_{2}$ flux measurements. An alternative approach for estimating this flux is to use the observed atmospheric concentrations of DMS in the boundary layer, in combination with a model for photochemistry and transport, to derive the flux which provides an internally consistent budget for atmospheric DMS. This latter approach also provides a means of estimating the emission flux of $\mathrm{H}_{2} \mathrm{~S}$, for which only aircraft concentration measurements are available. It further allows an estimate of the biogenic sources of $\mathrm{SO}_{2}$ and sulfate, which are determined by the rates of photochemical oxidation of the reduced sulfur precursors.

We present here a simulation of the biogenic sulfur cycle over the Amazon Basin, using a one-dimensional photochemical model for the boundary layer extending upward to $2000 \mathrm{~m}$. A detailed description of the model is given by Jacob and Wofsy [this issue] along with evaluations of model accuracy for $\mathrm{O}_{3}, \mathrm{NO}_{y}$, and hydrocarbons. The model includes a detailed representation of biosphere-atmosphere exchange, subdividing the canopy into three grid cells in order to resolve the vertical distributions of vegetation density, light penetration, and stomatal resistances. The leaf area index of the canopy is 7 , with highest vegetation densities near the bottom (undergrowth) and near the top (canopy crown). Vertical transport above the canopy is simulated by a diel cycle of mixed layer growth and decay, with mixed layer depths peaking at $1500 \mathrm{~m}$ at midday.

Five sulfur species are simulated as independent variables in the model: DMS, $\mathrm{H}_{2} \mathrm{~S}, \mathrm{MeSH}, \mathrm{SO}_{2}$, and sulfate. The species DMS, $\mathrm{H}_{2} \mathrm{~S}$, and MeSH are emitted by the forest; they are removed from the boundary layer by deposition to vegetation, oxidation to $\mathrm{SO}_{2}$, and ventilation to the free troposphere above $2000 \mathrm{~m}$. Sulfur dioxide produced by oxidation of DMS, $\mathrm{H}_{2} \mathrm{~S}$, and $\mathrm{MeSH}$ is removed from the boundary layer by deposition to vegetation, oxidation to sulfate, and ventilation to the free troposphere. Sulfate is removed by wet deposition and ventilation.

Oxidation of DMS, $\mathrm{H}_{2} \mathrm{~S}$, and $\mathrm{MeSH}$ by $\mathrm{OH}$ is assumed to produce $\mathrm{SO}_{2}$ with $100 \%$ yield. Rate constants are $k_{1}=5 \times$ $10^{-12} \mathrm{~cm}^{3} \mathrm{~s}^{-1}$ for $\mathrm{H}_{2} \mathrm{~S}+\mathrm{OH}$ [Cox and Sheppard, 1980], $k_{2}$ $=4.3 \times 10^{-12}\left(1+2.6 \times 10^{-3} P\right) \mathrm{cm}^{3} \mathrm{~s}^{-1}$ ( $\mathrm{P}$ in torrs) for $\mathrm{DMS}+\mathrm{OH}$ [Atkinson, 1986], and $k_{3}=9.7 \times 10^{-12} e^{366 / T}$ $\mathrm{cm}^{3} \mathrm{~s}^{-1}$ for MeSH + OH [Atkinson, 1986]. At night, DMS and $\mathrm{MeSH}$ are oxidized to $\mathrm{SO}_{2}$ by $\mathrm{NO}_{3}$, with rate constants $k_{4}=1.8 \times 10^{-13} e^{530 / T} \mathrm{~cm}^{3} \mathrm{~s}^{-1}$ and $k_{5}=1.1 \times 10^{-12} \mathrm{~cm}^{3}$ $\mathrm{s}^{-1}$, respectively [Dlugokencky and Howard, 1988]. The reaction of $\mathrm{H}_{2} \mathrm{~S}$ with $\mathrm{NO}_{3}$ is negligibly slow [Dlugokencky and Howard, 1988]. Sulfate is produced in the gas phase by the reaction $\mathrm{SO}_{2}+\mathrm{OH}$, with a rate constant dependent on pressure [Atkinson and Lloyd, 1984]. In addition, sulfate is produced by quantitative aqueous phase oxidation of $\mathrm{SO}_{2}$ during turbulent exchange at the top of the mixed layer, which we assume takes place mainly in shallow cumuli. Ventilation of $\mathrm{SO}_{2}$ from the mixed layer to the atmosphere above is allowed only during the late afternoon stratification of the boundary layer [cf. Jacob and Wofsy, this issue].

Sulfate aerosol is removed from the boundary layer by wet deposition with a time constant of 1 day [Andreae et al., this 
issue]. Sulfur gases are assumed not to be scavenged by rain, but are removed by dry deposition to vegetation which is simulated with a multilevel resistance-in-series scheme [Meyers and Baldocchi, 1988]. Stomatal resistances are specified as a function of vegetation height and time of day, on the basis of measurements at the ABLE 2B forest site [Roberts et al., 1990]. Mesophyllic and cuticular resistances for sulfur gases are assumed to be 0 and $200 \mathrm{~s} \mathrm{~cm}^{-1}$, respectively, on the basis of data for COS [Goldan et al., 1988].

The chemical evolution of the boundary layer is computed over a three-day simulation period, starting from initial concentrations representative of the free troposphere (Table 1) which are also taken as fixed upper boundary conditions at 2000-m altitude. The initialization is intended to simulate the passage of a major meteorological disturbance, when air from the free troposphere rapidly mixes with the boundary layer [Scala et al., this issue]. Relatively undisturbed conditions (characterized by a regular diel cycle of mixed layer growth and decay) are assumed to follow this initial disturbance and to persist for the duration of the simulation. As the simulation progresses, sulfur species approach a steady state between the sources and sinks given above. Between model day 2 and model day 3 the 24-hour average boundary layer concentrations of $\mathrm{H}_{2} \mathrm{~S}, \mathrm{DMS}, \mathrm{MeSH}$, and $\mathrm{SO}_{2}$ increase by $33 \%, 21 \%, 20 \%$, and $2 \%$, respectively, while the sulfate concentration decreases by $5 \%$. Measurements of ${ }^{222} \mathrm{Rn}$ from aircraft during $\mathrm{ABLE} 2 \mathrm{~B}$ suggest that the residence time of air in the boundary layer over the Amazon Basin was of the order of 3 days (E. B. Pereira et al., Radon concentration profiles over the Brazilian Amazon Basin during wet season, submitted to Journal of Geophysical Research, 1990). Therefore we will focus on results from model day 3 as representative of the boundary layer observed in ABLE 2B. All results below are taken from model day 3.

Our first objective is to derive the DMS emission flux from the forest. A constant DMS soil emission flux of $0.04 \mathrm{nmol}$ $\mathrm{m}^{-2} \mathrm{~min}^{-1}$ is included in the model, on the basis of the chamber measurements; however, as pointed out above, DMS emission from the forest appears to be mostly contributed by vegetation. We assume in the model that the DMS emission flux per unit area of leaf, $\Phi\left(\mathrm{nmol} \mathrm{m}^{-2}\right.$ leaf $\left.\mathrm{min}^{-1}\right)$, is dependent on the local air temperature $T$ and solar radiation $I$, as follows:

$$
\Phi=\Phi_{0} f(T) g(I)
$$

Based on the laboratory measurements of Fall et al. [1988], we adopt $f(T)=e^{0.1(T-298)}$, and $g(I)=1-e^{-I / 100}$, where $T$ is in units of $\mathrm{K}$ and $I$ is in units of microeinstein $\mathrm{m}^{-2} \mathrm{~s}^{-1}(1$ $\mathrm{W} \mathrm{\textrm {m } ^ { - 2 }}$ of solar radiation corresponds approximately to 9.2 microeinstein $\mathrm{m}^{-2} \mathrm{~s}^{-1}$ ). In (2), $\Phi_{0}$ is the emission flux from a leaf at $298 \mathrm{~K}$ exposed to full sun; we assume this flux to be a constant, independent of vegetation type, and adjust its value in the model to match the observed atmospheric concentrations of DMS. The total emission flux from the canopy is then obtained by integrating (2) over the total canopy depth, and subtracting the deposition fluxes computed from the leaf resistances. The detail of the computational procedure is given by Jacob and Wofsy [this issue] for the similar case of isoprene emission.

The adjustment of $\Phi_{0}$ in the model is straightforward because atmospheric concentrations of DMS almost scale

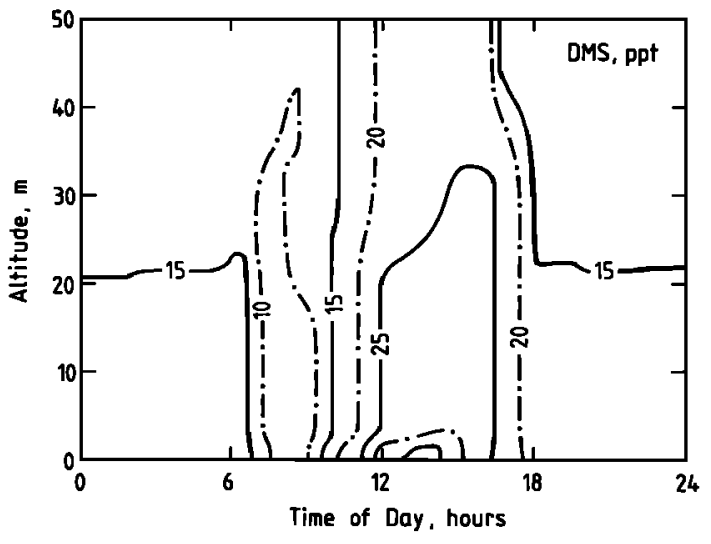

Fig. 10. Simulated concentrations of DMS (ppt) between 0 and 50 $m$, as a function of time of day.

linearly to $\Phi_{0}$. We find that a value $\Phi_{0}=0.2 \mathrm{nmol} \mathrm{m} \mathrm{m}^{-2}$ $\min ^{-1}$ gives a good simulation of the vertical profiles measured from aircraft (Figure 1), and also gives a reasonable simulation of DMS levels inside the canopy (Figure 10). The corresponding 24-hour average DMS emission flux at canopy top is $0.21 \mathrm{nmol} \mathrm{m}^{-2} \mathrm{~min}^{-1}$, lower than the value of $0.46 \pm$ $0.20 \mathrm{nmol} \mathrm{m} \mathrm{min}^{-1}$ estimated above from the observed concentration gradients at canopy top. The discrepancy between the two estimates is not unreasonable in view of the uncertainties involved in the model calculations and the gradient flux measurement, about a factor of 2 in both cases.

The diel variation of DMS emission in the model follows largely the diel variation of solar radiation (Figure 5). Emission from leaves at canopy top becomes light saturated shortly after sunrise, but in the lower canopy, light saturation is not achieved even at midday because of shading from the vegetation above. The midday peak of DMS emission in the model is somewhat less pronounced than that of isoprene emission [Jacob and Wofsy, this issue], reflecting the lower light saturation level for DMS than for isoprene [Tingey et al., 1979; Fall et al., 1988].

The emission flux of $\mathrm{H}_{2} \mathrm{~S}$ from vegetation was derived in the same way as for DMS, i.e., by assuming a functional dependence on $T$ and $I$ as described by (2). Soil emissions of $\mathrm{H}_{2} \mathrm{~S}$ were assumed negligible. In the case of $\mathrm{H}_{2} \mathrm{~S}$, only six atmospheric concentration measurements are available in the boundary layer, therefore the value of $\Phi_{0}$ was adjusted to match the average of these measurements. A value $\Phi_{0}=1.3$ nmol $\mathrm{m}^{-2} \mathrm{~min}^{-1}$ yields a 24-hour average boundary layer concentration of $45 \mathrm{ppt}$ in the model, which well reproduces the average value of $47 \mathrm{ppt}$ reported in Table 1 . The corresponding 24-hour average emission flux of $\mathrm{H}_{2} \mathrm{~S}$ at canopy top is $1.1 \mathrm{nmol} \mathrm{m}^{-2} \mathrm{~min}^{-1}$, which can be compared to the upper limit of $1.6 \mathrm{nmol} \mathrm{m} \mathrm{min}^{-1}$ estimated by Andreae and Andreae [1988] for the dry season on the basis of observed concentration gradients. The two estimates are consistent.

Sulfur dioxide and sulfate are produced in the model by oxidation of DMS, $\mathrm{H}_{2} \mathrm{~S}$, and MeSH. The MeSH emission flux is assumed $50 \%$ of the DMS flux, on the basis of dry season observations [Andreae and Andreae, 1988]. This results in a total emission of reactive sulfur gases (DMS, $\mathrm{H}_{2} \mathrm{~S}$, and $\left.\mathrm{MeSH}\right)$ of about $1.4 \mathrm{nmol} \mathrm{m}^{-2} \mathrm{~min}^{-1}(0.2+1.1+$ $0.1 \mathrm{nmol} \mathrm{m}^{-2} \mathrm{~min}^{-1}$ ). We show in Table 3 the 24-hour average model budgets for all sulfur species in the boundary 
TABLE 3. Model Budgets of Sulfur Species in the Boundary Layer

\begin{tabular}{|c|c|c|c|c|c|}
\hline & $\mathrm{H}_{2} \mathrm{~S}$ & DMS & $\mathrm{MeSH}$ & $\mathrm{SO}_{2}$ & $\mathrm{SO}_{4}^{=}$ \\
\hline $\begin{array}{l}\text { Concentration, ppt } \\
\text { Sources and sinks, ppt } \mathrm{d}^{-1}\end{array}$ & 44.5 & 4.7 & 2.0 & 12.6 & 8.9 \\
\hline Flux at canopy top* & +21.9 & +4.1 & +2.0 & -1.7 & -0.1 \\
\hline $\begin{array}{l}\text { Ventilation at } 2000 \mathrm{~m} \\
\text { Wet deposition }\end{array}$ & -7.7 & -0.5 & -0.2 & +0.6 & $\begin{array}{l}+0.2 \\
-8.9\end{array}$ \\
\hline $\mathrm{SO}_{2} \rightarrow \mathrm{SO}_{4}^{=}(\mathrm{aq})$ & & & & -8.3 & +8.3 \\
\hline $\mathrm{H}_{2} \mathrm{~S}+\mathrm{OH}$ & -5.7 & & & +5.7 & \\
\hline DMS + OH & & -2.8 & & +2.8 & \\
\hline $\mathrm{MeSH}+\mathrm{OH}$ & & & -1.4 & +1.4 & \\
\hline $\mathrm{DMS}+\mathrm{NO}_{3}$ & & -0.2 & & +0.2 & \\
\hline $\mathrm{MeSH}+\mathrm{NO}_{3}$ & & & -0.1 & +0.1 & \\
\hline $\mathrm{SO}_{2}+\mathrm{OH}$ & & & & -0.4 & +0.4 \\
\hline Accumulation, ppt $\mathrm{d}^{-1}$ & +8.5 & +.06 & +0.3 & +0.4 & -0.1 \\
\hline
\end{tabular}

Concentrations and rates are daily mean values for model day 3 averaged over the air column extending from $30 \mathrm{~m}$ (canopy top) to $2000 \mathrm{~m}$ (top of the boundary layer).

*Not including wet deposition.

layer. The simulated concentration of $\mathrm{SO}_{2}$ is $13 \mathrm{ppt}$, about half the average observed $\mathrm{SO}_{2}$ concentration of $24 \mathrm{ppt}$ (Table 1). However, the main sink for $\mathrm{SO}_{2}$ in the model is aqueous phase oxidation, which is poorly constrained. The production rate of $\mathrm{SO}_{2}$ in the model $\left(10 \mathrm{ppt} \mathrm{d}{ }^{-1}\right)$ suggests that biogenic emissions from the forest must account for a significant fraction of the $\mathrm{SO}_{2}$ levels observed in ABLE 2B. Other sources (e.g., transport from outside the Basin) could also be important.

The average sulfate concentration predicted by the model in the boundary layer ( $9 \mathrm{ppt}$ ) is at the low end of observed values (Figure 7) and is in reasonable agreement with the background concentration of $12 \mathrm{ppt}$ derived from the observations after removing the marine source characterized by $\mathrm{Na}^{+}$, and the anthropogenic source characterized by $\mathrm{NO}_{3}^{-}$ (equation (1)). It appears therefore that the background sulfate concentrations observed during ABLE 2B can be explained by biogenic emissions from the forest. Under most conditions, however, this biogenic background is small compared to the marine and anthropogenic contributions (Figures 7 and 8). A significant local source of $\mathrm{SO}_{2}$ from the photochemical oxidation of reduced biogenic sulfur gases and, in contrast, a predominantly advective origin of sulfate from long-range transport are consistent with the absience of any significant correlation between $\mathrm{SO}_{2}$ and sulfate in our data set.

\section{CONCLUSIONS}

The results of our studies on the sulfur cycle over Amazonia have led us to reevaluate roles played by biógenic emissions, marine aerosols, and long-range transport of combustion-derived sulfate aerosols in controlling the concentrations of sulfur species over the remote tropical continents. The reduced sulfur gas emissions from soils were low during the wet season, the DMS flux was about $0.04 \mathrm{nmol}$ $\mathrm{m}^{-2} \mathrm{~min}^{-1}$, the $\mathrm{H}_{2} \mathrm{~S}$ flux less than $0.03 \mathrm{nmol} \mathrm{m} \mathrm{min}^{-1}$. These fluxes are at the low end of the range observed from soils in the United States [Goldan et al., 1987; Lamb et al., 1987]. The DMS flux from the forest canopy, obtained by a gradient-flux technique, was $0.46 \pm 0.20 \mathrm{nmol} \mathrm{m} \mathrm{min}^{-1}$, similar to values measured in North America. The $\mathrm{H}_{2} \mathrm{~S}$ flux from the canopy was not measured directly. Model calculations based on the concentrations of DMS, MeSH, and $\mathrm{H}_{2} \mathrm{~S}$ in the planetary boundary layer (PBL) suggest that the canopy emission fluxes for these species were $0.2,0.1$, and $1.1 \mathrm{nmol} \mathrm{m} \mathrm{min}^{-1}$, respectively, for a total reactive reduced sulfur flux of about $1.4 \mathrm{nmol} \mathrm{m}^{-2} \mathrm{~min}^{-1}$. This flux is somewhat lower than our dry season estimate of $2.9 \mathrm{nmol}$ $\mathrm{m}^{-2} \mathrm{~min}^{-1}$ and in reasonable agreement with the measurements made in North America by Lamb et al. [1987]. When the ventilation of the reduced sulfur gases and $\mathrm{SO}_{2}$ from the boundary layer into the free troposphere and the dry deposition of $\mathrm{SO}_{2}$ are taken into account, the -oxidation of biogenic sulfur species can account for a $\mathrm{SO}_{4}=$ aerosol production of about $0.6 \mathrm{nmol} \mathrm{m} \mathrm{min}^{-1}$, only a small fraction of the wet deposition rate observed during ABLE 2B (7.4 nmol m $\mathrm{min}^{-1}$, or $\left.0.12 \mathrm{~g} \mathrm{~S} \mathrm{~m}^{-2} \mathrm{yr}^{-1}\right)$. The relationships between sulfate, nitrate, and sodium in aerosol and rain, as described by multivariate regression analysis, suggest that marine aerosols, including sulfate from the oxidation of marine biogenic dimethylsulfide, and combustion-derived sulfate aerosols brought into the Amazon Basin by long-range transport account for the remaining $\approx 90 \%$ of sulfate standing stock and deposition. Transport from outside the Amazon Basin has been implicated in the ABLE 2B observations for other species besides $\mathrm{SO}_{4}{ }^{=}$, e.g., $\mathrm{NO}_{y}$ [Bakwin et al., this issue (b); Jacob and Wofsy, this issue], aerosol [Talbot et al., this issue (a)], and organic acids [Talbot et al., this issue $(b)]$.

Based on our measurements in the wet and dry season, we estimate a mean annual reduced sulfur gas emission of about $2 \pm 1 \mathrm{nmol} \mathrm{m} \mathrm{m}^{-2} \mathrm{~min}^{-1}$ from the rain forest ecosystems of central Amazonia. The weak geographical gradients in sulfur species concentrations over Amazonia observed during both expeditions suggest that this estimate may be representative for all of the wet tropical regions of South America. In fact, it may be valid for the wet tropics worldwide, as suggested by our sulfur gas measurements in the PBL over the rain forest of equatorial Africa. Over the Congo forest we observed slightly lower concentrations of DMS and $\mathrm{H}_{2} \mathrm{~S}(5.3 \pm$ 4.5 and $25 \pm 16 \mathrm{ppt}$, respectively) than over Amazonia ( $\mathrm{H}$. G. Bingemer et al., Measurements of sulfur gases and aerosols in and above the Equatorial African rain forest, submitted to Journal of Geophysical Research, 1990). But in view of the somewhat shorter lifetime of the sulfur gases over Africa caused by higher $\mathrm{OH}$ levels, these concentra- 
tions are consistent with emission fluxes $\left(0.9-1.7 \mathrm{nmol} \mathrm{m}^{-2}\right.$ min $^{-1}$ ) similar to those measured in Amazonia. Assuming then, that a biogenic sulfur flux of $2 \pm 1 \mathrm{nmol} \mathrm{m}^{-2} \mathrm{~min}^{-1}$ is representative of the wet tropics worldwide, we find that this region is of minor importance in the global atmospheric sulfur cycle. Using $11.9 \times 10^{12} \mathrm{~m}^{2}$ as an estimate for the area covered by tropical forests [Brown and Lugo, 1984], we predict a sulfur emission flux of $13 \pm 6 \mathrm{Gmol} \mathrm{yr}^{-1}$ from the wet tropics. If the rest of the vegetated land surface $(88 \times$ $10^{12} \mathrm{~m}^{2}$ ) has an emission rate of $2.4 \mathrm{nmol} \mathrm{m} \mathrm{min}^{-1}$ (excluding COS), as estimated by Guenther et al. [1989] for the United States, the sulfur emissions from this area are

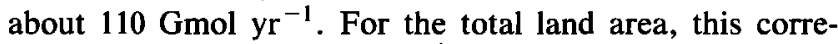

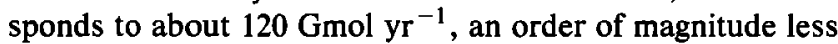
than the total oceanic flux of about $1 \mathrm{Tmol} \mathrm{yr}^{-1}$ [Andreae, 1986, 1990].

In contrast to earlier authors [Adams et al., 1981; Delmas and Servant, 1988], we conclude that the wet tropical continents make only a small contribution to the global atmospheric sulfur cycle, since they represent only about $3 \%$ of the Earth's surface and have a relatively low sulfur emission rate. The emissions from tropical wet forests account for only about $1 \%$ of global biogenic sulfur emissions. This is especially modest in comparison with anthropogenic emissions from fossil fuel burning (about $3 \mathrm{Tmol}$ $\mathrm{yr}^{-1}$ ). Even sulfur emissions from biomass burning in the tropics are substantially greater than the biogenic emissions (about 100 versus $13 \mathrm{Gmol} \mathrm{yr}^{-1}$ ) [Andreae, 1990]. Consequently, increasing industrial and economic development is expected to significantly perturb the atmospheric sulfur cycle in tropical regions, a hypothesis which is supported by our measurements of sulfate in aerosols and rain from Amazonia.

This perturbation of the sulfur cycle in the tropics is even more evident in tropical Africa, where the rainwater concentrations of sulfate and other species derived from biomass burning are substantially higher than in Amazonia. In the rain forest of the northern Congo, for example, J. P. Lacaux (personal communication, 1988) found a mean rainwater sulfate concentration 5 times higher than in Amazonia. Together with increased amounts of nitric and organic acids, this may result in significant acidification of tropical ecosystems [McDowell, 1988].

Acknowledgments. We acknowledge the permission of the government of Brazil to conduct this research in Brazil. We gratefully acknowledge the collaboration of the Brazilian Science Team under the leadership of J. R. B. Coelho. We thank H. Schubart and the Instituto Nacional de Pesquisas da Amazonia (INPA) for permission to work at the Ducke Forest Reserve, and the Harvard group (S. Wofsy, P. Bakwin, S.-M. Fan) for their collaboration at the Ducke site and for making their flux data available to us. The cooperation of the flight crew of the NASA Electra research aircraft is gratefully acknowledged. We thank C. Harris for help with the preparation of the manuscript and G. Feyerherd for drawing the figures. This research was supported by the NASA Tropospheric Chemistry Program (grant NAG-1-588), the U.S. National Science Foundation (grants ATM-8407137, ATM-8413153, ATM-8858074), and the Max Planck Society.

\section{REFERENCES}

Adams, D. F., S. O. Farwell, E. Robinson, M. R. Pack, and W. L. Bamesberger, Biogenic sulfur source strengths, Environ. Sci. Technol., 15, 1493-1498, 1981.

Andreae, M. O., The ocean as a source of atmospheric compounds, in The Role of Air-Sea Exchange in Geochemical Cycling, edited by P. Buat-Ménard, pp. 331-362, D. Reidel, Hingham, Mass., 1986.

Andreae, M. O., The global biogeochemical sulfur cycle: A review, in Trace Gases and the Earth System, edited by D. S. Schimel and B. Moore, University of Arizona Press, Tucson, in press, 1990.

Andreae, M. O. and T. W. Andreae, The cycle of biogenic sulfur compounds over the Amazon Basin, I, Dry Season, J. Geophys. Res., 93, 1487-1497, 1988.

Andreae, M. O., et al., Dimethyl sulfide in the marine atmosphere, J. Geophys. Res., 90, 12,891-12,900, 1985.

Andreae, M. O., H. Berresheim, T. W. Andreae, M. A. Kritz, T. S. Bates, and J. T. Merrill, Vertical distribution of dimethylsulfide, sulfur dioxide, aerosol ions, and radon over the northeast Pacific Ocean, J. Atmos. Chem., 6, 149-173, 1988.

Andreae, M. O., R. W. Talbot, H. Berresheim, and K. M. Beecher, Precipitation chemistry in central Amazonia, J. Geophys. Res., this issue.

Artaxo, P., H. Storms, F. Bruynseels, R. Van Grieken, and W. Maenhaut, Composition and sources of aerosols from the Amazon Basin, J. Geophys Res., 93, 1605-1615, 1988.

Artaxo, P., W. Maenhaut, H. Storms, and R. Van Grieken, Aerosol characteristics and sources for the Amazon Basin during the wet season, J. Geophys. Res., this issue.

Atkinson, R., Kinetics and mechanisms of the gas-phase reactions of the hydroxyl radical with organic compounds under atmospheric conditions, Chem. Rev., 86, 69-201, 1986.

Atkinson, R., and A. L. Lloyd, Evaluation of kinetic and mechanistic data for modeling of photochemical smog, J. Phys. Chem. Ref. Data, 13, 315-444, 1984.

Bakwin, P. S., S. C. Wofsy, S.-M. Fan, M. Keller, S. Trumbore, and J. M. da Costa, Emission of nitric oxide (NO) from tropical forest soils and exchange of NO between the forest canopy and atmospheric boundary layers, J. Geophys. Res., this issue (a).

Bakwin, P. S., S. C. Wofsy, and S.-M. Fan, Measurements of reactive nitrogen oxides $\left(\mathrm{NO}_{y}\right)$ within and above a tropical forest canopy in the wet season, $J$. Geophys. Res., this issue $(b)$.

Berresheim, H., M. O. Andreae, G. P. Ayers, R. W. Gillett, J. T. Merrill, V. J. Harris, and W. L. Chameides, Airborne measurements of dimethylsulfide, sulfur dioxide, and aerosol ions over the Southern Ocean south of Australia, J. Atmos. Chem., 10, 341370, 1990.

Brown, S., and E. Lugo, Biomass of tropical forests: A new estimate based on forest volumes, Science, 223, 1290-1293, 1984.

Cooper, D. J., and E. S. Saltzman, Uptake of carbonyl sulfide by silver nitrate impregnated filters: Implications for the measurement of low level atmospheric $\mathrm{H}_{2} \mathrm{~S}$, Geophys. Res. Lett., 14, 206-209, 1987.

Cox, R. A., and D. Sheppard, Reactions of $\mathrm{OH}$ radicals with gaseous sulphur compounds, Nature, 284, 330-331, 1980.

Daum, P. H., and D. F. Leahy, The Brookhaven National Laboratory filter pack system for collection and determination of air pollutants, Informal Rep. BNL 31381R, Brookhaven Natl. Lab., Upton, N. Y., 1983.

Delmas, R., and J. Servant, Atmospheric balance of sulfur above an equatorial forest, Tellus, 35B, 110-120, 1983.

Delmas, R., and J. Servant, The atmospheric cycle in the tropics, in Acidification in Tropical Countries, SCOPE 36, edited by $\mathrm{H}$. Rodhe and R. Herrera, pp. 43-72, John Wiley, New York, 1988.

Dlugokencky, E. J., and C. J. Howard, Laboratory studies of $\mathrm{NO}_{3}$ radical reactions with some atmospheric sulfur compounds, $J$. Phys. Chem., 92, 1188-1193, 1988.

Fall, R., D. L. Albritton, F. C. Fehsenfeld, W. C. Kuster, and P. D. Goldan, Laboratory studies of some environmental variables controlling sulfur emissions from plants, J. Atmos. Chem., 6, 341-362, 1988.

Fan, S.-M., S. C. Wofsy, P. S. Bakwin, and D. J. Jacob, Atmosphere-biosphere exchange of $\mathrm{CO}_{2}$ and $\mathrm{O}_{3}$ in the central Amazon forest, J. Geophys. Res., this issue.

Fitzjarrald, D. R., K. E. Moore, O. M. R. Cabral, J. Scolar, A. O. Manzi, and L. D. de Abreu Sá, Daytime turbulent exchange between the Amazon forest and the atmosphere, J. Geophys. Res., this issue.

Galasyn, J. F., K. L. Tschudy, and B. J. Huebert, Seasonal and diurnal variability of nitric acid vapor and ionic species in the 
remote free troposphere at Mauna Loa, Hawaii, J. Geophys Res., 92, 3105-3113, 1987.

Goldan, P. D., W. C. Kuster, D. L. Albritton, and F. C. Fehsenfeld, The measurement of biogenic sulfur emissions from soils and vegetation: Three sites in the eastern United States revisited, $J$. Atmos. Chem., 5, 439-467, 1987.

Goldan, P. D., R. Fall, W. C. Kuster, and F. C. Fehsenfeld, The uptake of $\operatorname{COS}$ by vegetation: A major tropospheric sink, $J$. Geophys. Res., 93, 14,186-14,192, 1988.

Guenther, A., B. Lamb, and H. Westberg, U.S. National Biogenic sulfur emissions inventory, Biogenic Sulfur in the Environment, ACS Symp. Ser., 393, 14-31, 1989.

Harriss, R. C., et al., The Amazon boundary layer experiment: Wet season 1987, J. Geophys. Res., this issue.

Jacob, D. J., and S. C. Wofsy, Budgets of reactive nitrogen, hydrocarbons, and ozone over the Amazon forest during the wet season, J. Geophys. Res., this issue.

Jaeschke, W., H. Claude, and J. Hermann, Sources and sinks of atmospheric $\mathrm{H}_{2} \mathrm{~S}, J$. Geophys. Res., 85, 5639-5644, 1980.

John, W., S. Hering, G. Reischl, G. Sasaki, and S. Goren, Characteristics of nuclepore filters with large pore size, II, Filtration properties, Atmos. Environ., 17, 373-382, 1983.

Kirchhoff, V. W. J. H., and E. V. A. Marinho, Surface carbon monoxide measurements in Amazonia, J. Geophys. Res., this issue.

Lamb, B., H. Westberg, G. Allwine, L. Bamesberger, and A. Guenther, Measurement of biogenic sulfur emissions from soils and vegetation: Application of dynamic enclosure methods with Natusch filter and GC/FPD analysis, J. Atmos. Chem., 5, 469 491, 1987.

Lodge, J. P., Jr., P. A. Machado, J. B. Pate, D. C. Sheesley, and A. F. Wartburg, Atmospheric trace chemistry in the American humid tropics, Tellus, 26, 250-253, 1974.

McDowell, W. H., Potential effects of acid deposition on tropical terrestrial ecosystems, in Acidification in Tropical Countries, SCOPE 36, edited by H. Rodhe and R. Herrera, pp. 117-139, John Wiley, New York, 1988.

Meyers, T. P., and D. D. Baldocchi, A comparison of models for deriving dry deposition fluxes of $\mathrm{O}_{3}$ and $\mathrm{SO}_{2}$ to a forest canopy, Tellus, 40, 270-284, 1988.

Molion, L. C. B., et al., Micrometeorological dynamics of a "terra firme" forest in central Amazonia during GTE/ABLE 2B mission, Eos Trans. AGU, 69, 320, 1988.

Natusch, D. F. S., H. B. Klonis, H. D. Axelrod, R. J. Teck, and J. P. Lodge, Jr., Sensitive method for measurement of atmospheric hydrogen sulfide, Anal. Chem., 44, 2067-2070, 1972.

Rennenberg, H., Synthesis and emission of hydrogen sulfide by higher plants, Biogenic Sulfur in the Environment, ACS Symp. Ser., 393, 44-58, 1989.

Roberts, J., O. M. R. Cabral, and L. F. De Aguiar, Stomatal and boundary-layer conductances measured in a terra firme rain forest, Manaus, Amazonas, Brazil, J. Appl. Ecol., in press, 1990.

Saltzman, E. S., D. L. Savoie, J. M. Prospero, and R. G. Zika, Methanesulfonic acid and non-sea-salt sulfate in Pacific air: Regional and seasonal variations, J. Atmos. Chem., 4, 227-240, 1986.

Savoie, D. L., J. M. Prospero, and E. S. Saltzman, Non-seasalt sulfate and nitrate in trade wind aerosols at Barbados: Evidence for long-range transport, J. Geophys. Res., 94, 5069-5080, 1989.

Scala, J. R., et al., Cloud draft structure and trace gas transport, $J$. Geophys. Res., this issue.

Staubes, R., H. W. Georgii, and G. Ockelmann, Flux of COS, DMS and CSc/2/2 from various soils in Germany, Tellus, $41 B, 305-313$, 1989.

Talbot, R. W., M. O. Andreae, T. W. Andreae, and R. C. Harriss, Regional aerosol chemistry of the Amazon Basin, J. Geophys. Res., 93, 1499-1508, 1988.

Talbot, R. W., M. O. Andreae, H. Berresheim, P. Artaxo, M. Garstang, R. C. Harriss, K. M. Beecher, and S. M. Li, Aerosol chemistry during the wet season in central Amazonia: The influence of long-range transport, J. Geophys. Res., this issue (a).

Talbot, R. W., M. O. Andreae, H. Berresheim, D. J. Jacob, and K. $M$. Beecher, Sources and sinks of formic, acetic, and pyruvic acids over central Amazonia, 2, Wet season, J. Geophys. Res., this issue $(b)$.

Tingey, D. T., M. Manning, L. C. Grothaus, and W. F. Burns, The influence of light and temperature on isoprene emission rates from live oak, Physiol. Plant., 47, 112-118, 1979.

Trumbore, S. E., Carbon cycling and gas exchange in soils, Ph.D. thesis, 194 pp., Columbia Univ., New York, 1988.

Walter, H., and S. W. Breckle, Ökologie der Erde, vol. 2, Spezielle Ökologie der Tropischen und Subtropischen Zonen, 461 pp., Fischer, Stuttgart, 1984.

M. O. Andreae and H. Bingemer, Biogeochemistry Department, Max Planck Institute for Chemistry, Postfach 3060, D-6500 Mainz, Federal Republic of Germany.

H. Berresheim, School of Geophysical Sciences, Georgia Institute of Technology, Atlanta, GA 30332.

D. J. Jacob, Department of Earth and Planetary Sciences and Division of Applied Sciences, Harvard University, Cambridge, MA 02138 .

B. L. Lewis, and S. M. Li, Department of Oceanography, Florida State University, Tallahassee, FL 32306.

R. W. Talbot, Institute for the Study of Earth, Oceans and Space, University of New Hampshire, Durham, NH 03824.

(Received September 29, 1989; revised March 13, 1990; accepted March 21, 1990.) 